\title{
Education for sustainable development in national tests: the case from Slovenia ${ }^{2}$
}

Summary: United Nations declared the period from 2005 to 2014 as a Decade of Education for Sustainable Development (DESD). This shows that nowadays education for sustainable development (ESD) is one of the priorities on the international and national levels. To find out if elements of ESD are present in Slovenian schools, we were analysing in the framework of a wider research project the Slovenian national curricula, textbooks, worksheets and national tests. In this paper, we are presenting the results of the analyses of national tests that 15 years old pupils write at the end of primary school. Based on fundamental documents for ESD, prepared by UNESCO, UNECE, European Union, United Nations and others, we constructed the criteria that define ESD. Fourteen keywords were determined and used in analyses of national tests, which were used in the school year 2005/06. Most elements of ESD were found in national tests for biology, some of them also in tests for Slovene language, while almost none were found in tests for mathematics. After 10 years the same analyses were made because we wanted to know if there was any effect of the DESD on Slovenian national tests. Comparative analyses of national tests used at the beginning and on completion of the DESD showed that in Slovenia we can hardly speak of a planned and systematic integration of ESD in national tests. This study shows the mirror to the authors of the national tests as well as the politicians that established the guidance of development of ESD.

Key words: Decade of education for sustainable development, education for sustainable development, national tests, national assessment, primary school.

1 darja.skribe-dimec@pef.uni-lj.si

2 Part of the work for this article was made in the framework of targeted research program "Competitiveness of Slovenia 20062013" Research Agency of the Republic of Slovenia. Project title: Analysis and encouraging the integration of education for sustainable development into primary schools. Project leader: DarjaSkribe-Dimec, Ph. D.

Copyright $\odot 2016$ by the authors, licensee Teacher Education Faculty University of Belgrade, SERBIA.

This is an open access article distributed under the terms of the Creative Commons Attribution License (CC BY 4.0) (https://creativecommons.org/licenses/by/4.0/), which permits unrestricted use, distribution, and reproduction in any medium, provided the original paper is accurately cited. 


\section{Introduction}

At the end of 2002, the UN designated the period 2005-2014 as the Decade of Education for Sustainable Development (hereinafter referred to as DESD) and assigned UNESCO to be a leading organization for the dissemination and implementation of that goal (UN, 2002). In 2005, at the highlevel meeting in Vilnius, the EU Ministers of Education and Environment prepared in the name of the United Nations a Strategy for Education for Sustainable Development (UNECE, 2005). These international documents prove that in an international context an education for sustainable development (hereinafter referred to as ESD) has become one of the priorities at the beginning of the 21st century.

In such activities Slovenia do not lag far behind the developed world. Already in 2006, in the context of Target research programmes of Slovenian Research Agency (2006) two research programmes which deal with education and education for sustainable development were started: Analysis and encouraging the integration of education for sustainable development into primary schools (principal researcher Darja Skribe Dimec) and Inclusion of the elements of sustainable consumption and sustainable development in school curriculum (principal researcher Justin Erčulj). Also already in 2007 the Slovenian Ministry of Education and Sports adopted and issued on the basis of the Strategy for Education for Sustainable Development the Guidelines for education for sustainable development from pre-school to pre-university education (ESD Guidelines, 2007). Even the Commission for monitoring and updating of curricula for interdisciplinary field of environmental education at the National Education Institute Slovenia prepared the text for schools and teachers to support the achievement of the objectives of environmental education (Zupan et al, 2008).

In this context, we must not overlook many activities that have been ongoing in Slovenian schools for many years, but they were not offi- cially "labelled" as ESD. Such case is a several decades old international project OECD / CERI Environment and school initiatives that took place between 1990 and in1994 (Marentič Požarnik et al., 1993), and a wide networks of Eco-Schools, Healthy Schools, UNESCO schools, etc. were established. First Healthy School and UNESCO schools have started operations in Slovenia in 1993. ECO schools were introduced in Slovenia in 1997. At the end of previous century curricula for primary school were renovated and a curriculum for environmental education, designed for intersubject cooperation was created (Marentič Požarnik et al., 1999).

In various documents we find similar, yet slightly different definitions of sustainable development and ESD. In most cases, the definitions are very general and cover the complex relationship between nature, society and economy. The ESD should achieve the following objectives: "This will equip people with knowledge of and skills in sustainable development, making them more competent and confident and increasing their opportunities for acting for a healthy and productive life in harmony with nature and with concern for social values, gender equality and cultural diversity." (UNECE Strategy for education for sustainable development, 2005: 2 ). The survey, which was carried out between Slovenian students, future teachers of primary education (Skribe Dimec, 2014), showed that the largest proportion of students (a little more than 40\%) connect the term "sustainable development" with the conservation of nature and other goods for future generations (the temporal view of environmental issues). The conception of these students is consistent with the most common definition (from the Brundtland Report) which defines sustainable development as "development that meets the needs of the present without compromising the ability of future generations to meet their own needs" (WCED, 1987). Many students connect sustainable development with a more general view expressed simply as "environmental or nature concerns" (21.7\%). The students' responses to the question about ESD 
were even more diverse than responses to the question about sustainable development. Greatest share of students (27\%) understand ESD as teaching and informing pupils about environmental pollution or the importance of a clean environment. Relatively often students mention the importance of pupils' awareness of the importance of environmental issues $(21.7 \%)$. The third most frequent opinion is encouragingly importance of responsible behaviour. These students are aware of both responsibility of the individuals, also pupils, as well as their acts or behaviour. Sustainable development is not entirely new topic. It is actually an extension of environmental education (Marentič Požarnik, 2007) and environmental education is an extension of ecology (Skribe Dimec, 2012). ESD raises Environmental Education to the broader context of socio-cultural as well as socio-political issues of equity, poverty, democracy and quality of life, as Golob (2007) summarized the text of the UNESCO document (2004).

Slovenia actually does not have a long tradition of national examination, since national tests started about 25 years ago. Below we summarize some general information about Slovenian national tests that we have obtained from the website of the National Examination Centre. In the school year 1991/92, a Common External Assessment of Knowledge in the mother language (Slovene, Italian or Hungarian) and Mathematics was introduced in the eight-year primary school programme as a component of the educational process. In 1999, primary education reform started in Slovenia with the gradual introduction of a nine-year primary education system. In the nine-year primary education programme, education was divided into three-year periods: the first, the second and the third, at the end of which pupils' knowledge was to be assessed by the National Assessment of Knowledge. A Final Examination of Knowledge of Pupils ${ }^{3}$ is held at the end of Period 3 in the year 9 (it happened for the first time in 2006). It is compulsory for all pupils. $\mathrm{Pu}-$

3 In this paper the expression "national test « is used. pils take tests in Slovene, Mathematics and either a modern foreign language or another optional subject. A third subject is determined each year by the Minister from the selection of compulsory subjects in Years 8 and 9 (Art Education, Biology, Chemistry, Citizenship and Ethics, Design and Technology, English, Geography, German, History, Musical Education, Physical Education, Physics). Final Examination of Knowledge of Pupils assumed the role of assessment of knowledge as its results were used to form final grades in the nine-year primary education programme and was one of the criteria for enrolment into secondary schools with limited enrolment. Changes in legislation brought several novelties in the school year 2005/06. Assessment at the end of Period 1 was abolished; however, the National Assessment of Knowledge at the end of Periods 2 and 3 remained mandatory. This form of assessment still exists today; pupils from Year 6 apply of their own accord; for pupils from Year 9, however, assessment is mandatory. In particular, the National Assessment of Knowledge at the end of Period 3 now has a different function and form as achievement in the National Assessment of Knowledge in Year 9 no longer bears any influence on the overall achievement in primary education; however, it can be considered as a criterion for the selection of candidates in cases of limited enrolment into secondary schools but only with previous agreement of pupils and their parents. The basic goal of the National Assessment of Knowledge, however, has remained unchanged despite the described changes: to acquire additional information or feedback on pupils' knowledge and to strive for a better quality of the learning and teaching processes.

As already mentioned, the national examinations at the end of the primary school each year included Slovenian language and mathematics. Biology was selected as the third subject in the school year 2005/06. From the perspective of ESD this is a very interesting subject, because the content of ESD among all academic subjects corresponds most closely with biology. Biology is the basic subject 
from which ecology and subsequently environmental education emerged (from a historical perspective, ecology is actually part of biology). Biology was selected for national examinations in 2009, 2011 and 2014 and will turn again in 2017.

In early 2007, two years after the commencement of the Decade, UNESCO brought together a group of experts from various regions around the globe to form the UN DESD Monitoring and Evaluation Expert Group (Tilbury, 2007). “The UN International Implementation Scheme for the Decade (UNESCO 2004) calls for the development of relevant and suitable indicators at all levels. It interprets monitoring and evaluation as one of the seven key strategies for implementing the Decade. The process of monitoring and assessment offers an opportunity to engage stakeholders in DESD activities, thus it can be more than just measuring performance"wrote Tilbury (2007: 240). The value of indicators lies in their ability to show information about a system that is not always visible or easily measured (Eder, 2004). According to Tilbury (2007) the indicator can help those seeking to meet targets to improve opportunities and standards in ESD. Determining what information to measure or observe through indicators depends on the clarity of the DESD goals and the specific targets defined. Tilbury (2007) presented evaluation framework, which includes different levels of indicators. Three main categories: status, facilitative indicator and effect are divided into eight indicators: baseline indicator, context indicator, process indicator, learning indicator, output indicator, outcome indicator, impact indicator and performance indicator. Tilbury demonstrates the importance of the implementation of indicators as: "Assessing progress and documenting learning during DESD is an ambitious undertaking - particularly since many actors are still trapped in definitional disputes or see ESD as primarily the concern of formal educators". (Tilbury, 2007: 252).

\section{The aim of the research}

To find out how elements of sustainable development are included in Slovenian schools we analysed curricula, textbooks, workbooks and national tests in the framework of research entitled Analysis and encouraging the integration of education for sustainable development into primary schools ${ }^{4}$. Analyses of the material in use in primary schools, which in our opinion significantly affect the knowledge, process skills and attitudes of pupils were made in order to empower us, based on the results obtained and the theoretical bases (international and national documents ESD), to propose a comprehensive strategy for ESD. The strategy should include both a theoretical model of ESD, as well as guidelines for development of materials and workshops for the training of primary school teachers. With analyses of national tests, we wanted to determine whether the ESD elements are included in national tests, as well as which elements are included, in what way, and to what extent. This is important because it is known that national tests can as a feedback affect the contents and methods of teaching in primary school. With national tests, the educational authorities show their attitude to knowledge. The analyses were done in 2006 with the purpose of finding out what the situation is at the beginning of the DESD, and again in 2015, at the end of the DESD. A comparison of the two analyses can tell us if and to what extent the objectives, which were formed after the announcement of this DESD were achieved in Slovenian national tests at the end of compulsory schooling.

\section{Methodology}

The research group in the first phase analysed the basic relevant documents issued by international

4 Project Competitiveness of Slovenia in the year 2006-2013 was held under the Ministry of Education and Sport. 
organizations such as UNESCO, UNECE, European Union, United Nations and others. These documents represent the basic legal and contextual basis for implementation of sustainable development in schools. As a result of the review of these documents, we have formed a set of criteria. For identifying keywords, we used as an additional source the Slovenian document entitled Guidelines for Education for Sustainable Development from pre-school to pre-university education. For the analyses of curricula, textbooks, workbooks and national tests, we have identified the following 14 keywords: SUSTAINABLE DEVELOPMENT, ECOLOGY, HEALTHY LIFESTYLE, WATER, GLOBALIZATION, EXTRACURRICULAR ACTIVITIES, COOPERATIVE LEARNING, CRITICAL THINKING, DEMOCRACY, ACTIVE CITIZENSHIP, TOLERANCE, NON-VIOLENCE, SELF-ESTEEM, POSITIVE SELF-IMAGE.

For this analysis, the qualitative research method was used. The first stage of analysis of national tests was automated search for keywords in the text. The second stage was based on empathic insight into tasks and learners. Based on the content and the cognitive level of complexity of the tasks we have tried to find connections with the identified keywords.

The analysis included all national tests that pupils wrote at the end of primary school. In the school year 2005/06, pupils wrote national tests for Slovenian language, mathematics and biology. The same subjects were included in national tests in the school year 2013/14 and we choose this year because we are thus able to compare the changes in all three subjects. We analysed the complete texts, which were given to pupils. National tests were obtained from the Internet on the website of the National Examination Centre.

\section{Results}

With the help of an automated search for our fourteen keywords, we have found in the national tests for Slovenian language, mathematics and biology for the year 2006 only word WATER. Word water has been included in the text in one task from the test for mathematics and in two tasks from the test for biology. We cannot conclude in any of three cases that the use of the word water is in fact reasonably strongly related to the objectives of ESD. In the tests for 2014, we found only the word SELF-CONFIDENCE in a test for Slovenian language. The word was used in the introductory text, but no task in a test associated with that word because it was used only to describe one of the main characters.

All other findings are based on the empathetic insight into tasks and learners. All three subjects included in the national examination have preliminary instructions for pupils on the first page. Although for each subject texts differ slightly, the basic text in all three is the same. The sentence: "Trust in yourself and your abilities." can be found in this text and we presume that this sentence can be associated with keywords CONFIDENCE and POSITIVE SELF-IMAGE. From this, we can conclude that the official test developers at the National Examination centre provide integration of ESD in national tests in a pleasant way.

\section{National test for Slovenian language (2006)}

The test has 15 pages and two-part structure. Pupils receive two introductory texts from which tasks or questions are formed. The first introductory text, entitled "We are looking for the most beautiful Slovenian word" is taken from Jana magazine, December 2004 . Text is followed by 18 tasks. The other introductory text is a poem written by JakaKošir and entitled "I write". Text is followed by 12 tasks.

In the first part of the test we did not find any tasks that would relate to the identified keywords. Perhaps we can say only that introductory text indirectly guides the pupils to ACTIVE CITIZENSHIP. The text is in fact an article from the magazine that invites all readers to participate in a competition for the most beautiful Slovenian word. 
In the second part of the test, in the task number 12 pupils are expected to possess the knowledge that could be included in CRITICAL THINKING, which is also one of the identified keywords. In this task the pupils have to compare the two songs and figure out how they are similar and how they differ regarding the topic and form. Beside that they should write a text that has more than 5 sentences.

\section{National test for Slovenian language (2014)}

The test has 16 pages. The structure of the test is the same as the structure, which was used in 2006. The first introductory text is entitled "Flying cats" and it is an excerpt from the book Zupan, D. (1997). Flying cat. Ljubljana: Mladinska knjiga. Text is followed by 12 tasks. The introductory text for the second part of the test is entitled "Dragonja and salt pans". The text is adapted from the magazine Gea, in February 2011, authored by Sebastian Vehar, under the heading "Let's ride bicycles". Text is followed by 16 tasks.

Here, too, we can say that first introductory text is associated with ESD, as the passage describes selling books door-to-door, which could be linked with ACTIVE CITIZENSHIP. In addition, SELFCONFIDENCE of one of the main characters is mentioned in the text. We could also link the text with the keyword POSITIVE SELF-IMAGE, because it can be deduced from the dialogues between the main characters. Even the keyword DEMOCRACY could be attributed to introductory text, since the conversation between the main characters is an example of democratic behaviour. We found two tasks that relate to our chosen keywords. One task in the text says: "... unselfish fighters for the mental well-being of the nation .... This task can be associated with ACTIVE CITIZENSHIP. The second task requires the pupil to decide whether he/she would recommend to his/her classmate a literary text from which the introductory text was taken. Task also requires the justification of this decision. It is estimated that CRITICAL THINKING is required.
The second introductory text is extremely suitable for the promotion of ESD. Firstly, because it promotes bicycling, that may be attributed to a HEALTHY LIFESTYLE. In addition, cycling through the saltpans, which are a protected area, is proposed. This can be associated with the keyword ECOLOGY. The text also describes traditional life of salt makers, which is in the context of SUSTAINABLE DEVELOPMENT.

We found five tasks relating to the ESD. One task is assigned to the keyword GLOBALIZATION because it warns pupils that names of some places on the map are written in Slovenian language and Italian language. Pupils must substantiate this fact. Two tasks specifically mention the beauty and tranquillity of nature, so we connected these two tasks with the word ECOLOGY. That word, in our opinion of all fourteen keywords is associated most with the aesthetic aspects of the environment, therefore, biotic and abiotic factors of the environment. Although the activity in one task is completely linguistic (classification of words), the starting sentence for this task is focused on the traditional salt production, therefore we associate this task with the keyword SUSTAINABLE DEVELOPMENT. The last task is from the ESD point of view an example of extremely good work. The task requires the pupils to empathize with the fictional pupil Novak, who attended "school in nature" at the Centre for School and Outdoor Education. With classmates he went to the cycling trip along the path, which is presented in the second introductory text. The task requires that the pupil writes to the Head of Centre for School and Outdoor Education to thank for the good organization of the trip. This study was attributed to the following keywords: HEALTHY LIFESTYLE (imaginary cycling), EXTRACURRICULAR ACTIVITIES (Centre for School and Outdoor Education) and CRITICAL THINKING (acknowledgment). 


\section{National test for mathematics (2006)}

The test has 19 pages and the following structure: one page of instructions and advices for solving the tasks, one side of annexes and 16 tasks. Most of the tasks are written on one page and have several sub-questions and tasks.

We found two tasks in which we could identify elements of ESD. One task in the text includes bike riding, which we connected with the keyword HEALTHY LIFESTYLE. The second task describes combustion of car fuel in the city and outside it and can be associated with the keyword ECOLOGY (pollution). Although we have found a keyword WATER in the test, this task, however, is not associated with ESD. The water in the task is used only to introduce the measurement of volume.

\section{National test for mathematics (2014)}

The test has 15 pages. The structure of the test is very similar to the structure of the test, which was used in 2006. The test has 11 tasks.

In the test we found just one task associated with ESD. It is related to the calculation of the annual membership fee in a tennis club. We connected it with the keyword HEALTHY LIFESTYLE.

\section{National test for biology (2006)}

The test has 12 pages, 20 tasks and two annexes. Test does not have a specific, clearly visible structure. The first 12 tasks are multiple-choice questions with four possible choices. The remaining tasks have sub-questions; they are a kind of thematic tasks, in which questions to complement are prevailing.

Regarding the elements that define ESD, we found in the test, as we expected, quite a few tasks that can be linked to ESD, because among all school subjects, biology has most direct opportunities for that. This can be justified by the fact that ecology is a part of biology, and biology "owns" a large proportion of environmental education.
Regarding ECOLOGY (which is one of the specified keywords), the following tasks are related: number four (stability of ecosystems), number five (endangered species), number 17.2 (food chain - removing aphids organically), number 18 (insecticides), number 19.1 (frogs' environment), number 19.3 (use of frogs for human food) and number 19.4 (frogs run over by cars). Direct elements of ESD are found in task number 17.1, as pupils are placed in a real situation of a farmer who has to choose a plant that will grow best in the fields, where there is no irrigation system. The task was connected with the keyword SUSTAINABLE DEVELOPMENT. Similarly, the task number 18, which refers to insecticides, was identified as the task that directs pupils toward SUSTAINABLE DEVELOPMENT because pupils are confronted with the problem of a dramatic impact of insecticides on environment. Tasks number 19.3 and number 19.4 require the pupils to identify themselves with the role of responsible citizens that save frogs (keyword is ACTIVE CITIZENSHIP). Although the task number 20 asks for biological facts, we can recognize in it the elements of ESD, especially in positive attitude toward animals. Such attitude is reflected in the attention that an imaginary pupil Nejc, presented in the text of this tasks, paid to ladybug. This attention is demonstrated in the following sentences:

\footnotetext{
"Nejc was watching closely ladybird with a magnifying glass."

»Nejc will prepare a vivarium in which ladybird will live."

"When Nejc was gathering material for vivarium...."
}

We connected this task with the keyword ECOLOGY, because in our set of keywords we did not have more appropriate keyword that would represent a positive attitude towards animals. Also interesting is the sentence: "Nejc already know that ladybugs are living on the meadow .... In this statement, it is possible to detect the promotion of SELFESTEEM and POSITIVE SELF-IMAGE because a pupil can relate it to his/her knowledge. The merit 
of this task is that pupil is placed in a concrete, real situation ("Nejc was just learning biology when it ..."). In this task we can indirectly detect an element of COOPERATIVE LEARNING because the task requires the pupil to help Nejc (a boy who appears in the text) with the advice ("In planning help him with your advice."). The task number 13 is another task that is related to ESD. The pupil is faced with the problem of diabetes. We connected this task with the keyword HEALTHY LIFESTYLE (proper diet in diabetes).

\section{National test for biology (2014)}

The text has 16 pages, 22 tasks and two annexes. The structure of the test is similar to the test used in 2006.

Also in this test, we found a number of tasks which we can connect with the keyword ECOLOGY. Such tasks are: task number 5 (decomposition of organic waste), task number 11 (diversity and evolution), task number $15 \mathrm{~b}$ (adaptation to the environment) and task number $18 \mathrm{~b}$ (natural balance in nature). With the keyword SUSTAINABLE DEVELOPMENT, we connected the following tasks: task number 3 (antibiotic resistance) and task number 17 (storage of fruits and vegetables). Task number $14 \mathrm{~b}$ can be connected with a HEALTHY LIFESTYLE, as increased heart rate during physical activity is mentioned.

\section{Discussion}

Analyses of national tests conducted by the National Examination Centre in the school years 2005/06 and 2013/14 revealed interesting findings in terms of presence of elements of ESD. Results of analyses of text and tasks of national tests for Slovenian language, mathematics and biology are summarized in Table 1.

From the Table 1 it is evident that the text used on the first page of all six tests was designed to foster self-confidence and positive self-esteem of pupils. We are pleased that the groups that have prepared the national tests were able to raise the awareness of and implemented such an approach.

Commission for Slovenian language prepares interesting national tests. The very structure of the test shows the desire of authors that the tasks are associated with everyday life, as the starting point of the text is always taken from the real sources. In 2006 there was only one task among 30 tasks in the test, which we could associate with the words that define the ESD. But the introductory text is indirect encouragement to pupils for active citizenship, as it is an invitation to participate in the competition "We are looking for the most beautiful Slovenian word". Completely different are the results for 2014. The second introductory text is an invitation to a cycling trip, which we connected with even three keywords that define the ESD. Seven tasks in the test are linked to the ESD keywords. An example of an excellent task, which covers several aspects of ESD, is the last one, which we connected with healthy lifestyle, extracurricular activities and critical thinking as the pupils have to write to the Head of Centre for School and Outdoor Education a letter to thank for the good organization of the cycling trip. This clearly demonstrates that the test for Slovenian language encourages and enables ESD.

Analysis of tests for mathematics showed that there are very few tasks for which we can say that they are at all related to the pupil's everyday life, that is, "to withdraw pupil from the strict school experience". Commission that develop mathematical tasks for national tests should in our view use more opportunities to link school and everyday life of pupils, or better connect theory with practice. There should be much more tasks that would place pupils in real life situations and real life problems. From the 16 analysed tasks for 2006, there were only two tasks in which we found content that can be linked with ESD, and only 1 out of 11 for 2014. Based on this analysis, we can say that in preparing tasks for the national test for mathematics there is a huge un- 
Table 1. Analyses of national tests for Slovenian language, mathematics and biology in terms of presence of elements of ESD.

\begin{tabular}{|c|c|c|c|c|c|c|c|c|}
\hline & \multicolumn{2}{|c|}{$\begin{array}{l}\text { National test for } \\
\text { Slovenian language }\end{array}$} & \multicolumn{2}{|c|}{$\begin{array}{l}\text { National test for } \\
\text { mathematics }\end{array}$} & \multicolumn{2}{|c|}{ National test for biology } & \multicolumn{2}{|c|}{ sum } \\
\hline & 2006 & 2014 & 2006 & 2014 & 2006 & 2014 & 2006 & 2014 \\
\hline $\begin{array}{l}\text { SUSTAINABLE } \\
\text { DEVELOPMENT }\end{array}$ & & $\underline{\checkmark} \checkmark$ & & & $\checkmark \checkmark$ & $\checkmark \checkmark$ & 2 & $3+\underline{1}$ \\
\hline ECOLOGY & & $\checkmark \checkmark \checkmark$ & $\checkmark$ & & $\checkmark \checkmark \checkmark \checkmark \checkmark \checkmark \checkmark \checkmark$ & $\checkmark \checkmark \checkmark \checkmark$ & 9 & $6+1$ \\
\hline HEALTHY LIFESTYLE & & $\checkmark \checkmark$ & $\checkmark$ & $\checkmark$ & $\checkmark$ & $\checkmark$ & 2 & $3+\underline{1}$ \\
\hline WATER & & & & & & & 0 & 0 \\
\hline GLOBALIZATION & & $\checkmark$ & & & & & 0 & 1 \\
\hline $\begin{array}{l}\text { EXTRACURRICULAR } \\
\text { ACTIVITIES }\end{array}$ & & $\checkmark$ & & & & & 0 & 1 \\
\hline $\begin{array}{l}\text { COOPERATIVE } \\
\text { LEARNING } \\
\end{array}$ & & & & & $\checkmark$ & & 1 & 0 \\
\hline CRITICAL THINKING & $\checkmark$ & $\checkmark$ & & & & & 1 & 2 \\
\hline DEMOCRACY & & $\checkmark$ & & & & & 0 & $\underline{1}$ \\
\hline ACTIVE CITIZENSHIP & $\checkmark$ & $\overline{\checkmark \checkmark}$ & & & $\checkmark$ & & $1+\underline{1}$ & $1+\underline{1}$ \\
\hline TOLERANCE & & & & & & & 0 & 0 \\
\hline NON-VIOLENCE & & & & & & & 0 & 0 \\
\hline SELF-ESTEEM & $\nabla$ & $\nabla \checkmark$ & $\nabla$ & $\nabla$ & $\nabla \checkmark$ & $\nabla$ & $1+3$ & $\underline{1}+3$ \\
\hline POSITIVE SELF-IMAGE & $\nabla$ & $\nabla \checkmark$ & $\nabla$ & $\nabla$ & $\nabla \checkmark$ & $\nabla$ & $1+3$ & $\underline{1}+3$ \\
\hline sum & $1+\underline{1}+2$ & $9+\underline{7+2}$ & $2+2$ & $1+2$ & $15+2$ & $7+2$ & $18+\underline{1}+6$ & $17+\underline{7}+6$ \\
\hline Number of all tasks & 30 & 28 & 16 & 11 & 20 & 22 & 66 & 61 \\
\hline
\end{tabular}

Legend: $\checkmark=$ task in the test;

$\nabla=$ first page: preliminary instructions for pupils;

$\checkmark=$ introductory texts for national test for Slovenian language.

used potential - also in terms of ESD. Commission that developed test should be inspired by tasks used in the international study PISA (Program for International Student Assessment).

For Slovenian language, it has been shown that the national test for 2014 was considerably more oriented towards ESD then the test for the year 2006, but in biology the situation is opposite. The group, which has made national tests for biology, has developed a number of tasks in which we can detect elements of ESD. This was expected because the curricula for biology included both ecology and environmental education. Among all the analysed tasks for biology, regarding the interestedness of approach and "indirect hints" for ESD, the task number 20 for the year 2006 was the best one. This task could serve as a good example for combination of assessment of biological facts with the inclusion of various ESD elements, even those that define the keywords "confidence" and "positive self-image". In contrast with the 2006 biology test, the analysis of the test used in 2014 was somewhat disappointing; because of 22 tasks, only seven were associated with ESD.

\section{Conclusions}

As expected, the most common are the elements of ESD in national tests for biology. We also found elements of ESD in the tests for Slovenian lan- 
guage. We were surprised that the introductory texts for both years (2006 and 2014) were related to ESD. National tests for mathematics however are only marginally related to ESD although, in our view, the texts of mathematical problems could be good way to indirectly promote ESD. An interesting element of ESD has been found in the preliminary instructions for pupils for all three-study subjects. Comparative analyses of national tests used at the beginning and on completion of the DESD showed that in Slovenia we can hardly speak of a planned and systematic integration of ESD in national tests. While the test for Slovenian language at this period significantly increased, the number of tasks associated with ESD there has been on the other hand a significant reduction of tasks associated with ESD in the national test for biology. From this, we can draw the conclusion that the integration of ESD may just be incidental, so we cannot completely confirm the positive effects of the DESD on Slovenian national tests. An interesting study was done in Sweden, where they also observed the effect of implementation of education for sustainable development in compulsory schools at the end of the DESD and found that the ESD had a slightly positive effect only in the 6th grade, while just the opposite, the impact in 9th grade has been even negative (Olsson et al. 2016).

The analyses that were based on a set of keywords associated with ESD showed that in the national tests we did not find content that could be linked to the following keywords: WATER, TOLERANCE and NON-VIOLENCE. We could directly or indirectly connect all other selected keywords with the text and tasks in national tests. National tests written for Slovenian pupils demonstrate that the tests could be means for the development of ESD, but they are far from used to the full possibilities. At least the keyword WATER would be easy to use in tasks for national tests, if we want that the ESD will not be discussed only at the declarative level. With this we will materialise good intentions in practice, both at the level of teaching and at the level of assessment, carried out with the national tests by the teachers themselves and by the government. The latter is even more important, because we know that with the national tests countries strongly influence teaching, regardless of whether that impact is positive or negative (Skribe-Dimec, 2007). We believe that even in a regular primary school curriculum there would be more connections to the ESD if the elements for sustainable development would be systematically included in national tests.

For analyses presented in this paper, we used national tests for Slovenian language, mathematics and biology; the latter was in the school years 2005/06 and 2013/14 chosen as the third subject. Regardless which subjects were chosen by the Ministry of Education and Sport as the third subject for national examination ${ }^{5}$, we should be aware that the groups that develop national tests could systematically include elements of ESD in any subject because Strategy for Education for Sustainable Development UNECE (2005) considered as the ESD main themes the following: citizenship, peace, ethics, responsibility in local and global contexts, democracy, justice, security, human rights, poverty reduction, health, gender equality, cultural diversity, rural and urban development, economy, production and consumption patterns, corporate responsibility, environmental protection, natural resource management and biological and landscape diversity. From this list it is

5 In the school year 2005/06 biology was chosen for the third subject of national tests for all pupils. The following years different subjects werechosen for the third subject (Ministry determine different subjects for individual schools). In 2006/07 following subjects were chosen: chemistry, physics, history and a foreign language in 2007/08: physics, engineering and technology, geography and history, in 2008/09: biology, physical education, foreign language and patriotic and civic culture and ethics in 2009/10: chemistry, history, fine arts and engineering and technology, in 2010/11: biology, geography and foreign language in 2011/12: physics, chemistry, music, art, patriotic and civic culture and ethics in 2012/13: geography, history, foreign language and engineering and technology, in the year 2013/14; physics, biology, foreign language, music and art, in the year 2014/15: foreign language, chemistry, engineering and technology, patriotic and civic culture and ethics in 2015/16: physics, history, fine arts and foreign language. 
clear that it is possible to create most of the tasks in the national tests in a way that takes into account the main themes of ESD.

In 2014, the DESD came to an end. Based on theirs and others results Olsson et al. (2016) argue that that after 10 years we know very little about the ESD implementation and its possible effects on pu- pils. They suggest that decisions and recommendations for the next DESD should be based on facts and empirical evidence rather than political ideas. With this study we want to show the mirror to the authors of the national tests as well as politicians that established the guidance of development of ESD.

\section{References}

- Council of the European Union (2005). Communication from the Commission to the Council and the European Parliament. On the review of the Sustainable Development Strategy. A platform for action. Brussels: Commission of the European Communities.

- Eco-Schools. Retrieved October 20, 2016. from www: http://www.ekosola.si/uploads/2010-08/Porocilo_ slovenskih_eko\%C5\%A1ol_2012_13.pdf.

- Eder, D. J. (2004). General Education Assessment within the Disciplines. The Journal of General Education. 53 (2), 135-157.

- Golob, N. (2007). Smiselni aktivizem. Vzgoja. 9 (4), 10-11.

- Healthy Schools. Retrieved October 20, 2016. from www: http://www.nijz.si/sl/slovenska-mreza-zdravih-sol.

- Marentič Požarnik, B. et al. (1993). Okolje in šolske iniciativ. Zgodba nekega projekta. Ljubljana: Zavod RS za šolstvo.

- Marentič Požarnik, B., Milekšič, V., Plut, D., Šorgo, A., Pavšer, N. \& Pukl, V. (1999). Okoljska vzgoja. Učni načrt za izbirne predmete. Ljubljana: Ministrstvo za šolstvo in šport, Nacionalni kurikularni svet.

- Marentič Požarnik, B. (2007). Razširitev okoljske vzgoje. Vzgoja. 9 (4), 12-14.

- Ministry of Education and Sport. Retrieved October 20, 2016. from www: http://www.mss.gov.si/si/delovna_podrocja/razvoj_solstva/.

- National Examination Centre (RIC). Nacionalno preverjanje znanja. Retrieved October 20, 2016. from www: http://www.ric.si/national_assessment_of_knowledge/general_information/.

- National Examination Centre (RIC). Preverjanje znanja. Retrieved October 20, 2016. from www: http:// www.ric.si/preverjanje_znanja/predmeti/.

- Olsson, D., Gericke, N. \& Chang Rundgren, S. N. (2016). The effect of implementation of education for sustainable development in Swedish compulsory schools - assessing pupils' sustainability consciousness. Environmental Education Research. 22 (2), 176-202. DOI:10.1080/13504622.2015.1005057.

- PISA. https://www.oecd.org/pisa/.

- Skribe Dimec, D. (2007). S preverjanjem znanja do naravoslovne pismenosti. Ljubljana: DZS.

- Skribe Dimec, D. (2012). Odnos do okolja. Šolski razgledi. 63 (3), 13. Retrieved October 23, 2016. from www: http://www.solski-razgledi.com/e-sr-prispevek.asp?ID=714.

- Skribe Dimec, D. (2014). Prihodnji učitelji razrednega pouka o vzgoji in izobraževanju za trajnostni razvoj. Vzgoja in izobraževanje. 45 (4), 26-30. 
- Slovenian Research Agency (ARRS) (2006). Retrieved October 20, 2016. from www: http://www.mizs.gov. si/si/delovna_podrocja/urad_za_razvoj_izobrazevanja/razvojno_raziskovalne_studije_crp/izbrani_projekti_2006_2013/.

- Smernice VITR (2007). Smernice za vzgojo in izobraževanje za trajnostni razvoj od predšolskega do douniverzitetnega izobraževanja. Ljubljana: Ministrstvo za šolstvo in šport.

- Tilbury, D. (2007). Monitoring and Evaluation during the UN Decade of Education for Sustainable Development. Journal of Education for Sustainable Development. 1 (2), 239-254.

- UN (2002). United Nations Decade of Education for Sustainable Development 57/254. Resolution adopted by the General Assembly. Retrieved October 20, 2016. from www: http://www.un-documents.net/a57r254.htm.

- UNECE (United Nations Economic Commission for Europe) (2005). Vilnius Framework for the Implementation of UNECE Strategy for Education for Sustainable Development. Retrieved October 20, 2016. from www: http://www.unece.org/fileadmin/DAM/env/documents/2005/cep/ac.13/cep.ac.13.2005.3.rev.1.e.pdf.

- UNESCO (2004). United Nations Decade of Education for Sustainable Development 2005-2014. Paris: UNESCO.

- UNESCO (2006). Framework for the UNDESD. International Implementation Scheme. Paris: UNESCO.

- UNESCO school. Retrieved October 20, 2016. from www: https://www.unesco-sole.si/o-mrezi/zgodovina. html.

- World Conference on Environment and Development - WCED (1987). Our Common Future. New York: Oxford University Press.

- Zupan, A., Marentič Požarnik, B., Vovk Korže, A. \& Orel, M. (2008). Okoljska vzgoja kot vzgoja in izobraževanje za trajnostni razvoj. Ljubljana: Ministrstvo za šolstvo in šport, Zavod RS za šolstvo. Retrieved October 20, 2016. from www: http://www.zrss.si/pdf/OKO OKO K Okoljska vzgoja obvezni-O\%C5\%A0..PDF. 


\section{Дарја Скрибе Димец}

Универзитет у Љубљани, Учитељски факултет, Словенија

\section{Образовање за одрживи развој у националним тестовима: пример Словеније}

Резиме: Ујеgиюене нације йроїласиле су крајем 2002. їоgине йериоg оg 2005. go 2014. ìogине Деценијом образоваюа за одрживи развој (Decade of Education for Sustainable Development (ДЕСД)). То йоказује gа је на йочеику 21. века образовање за оgрживи развој (education for

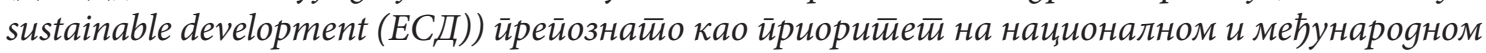

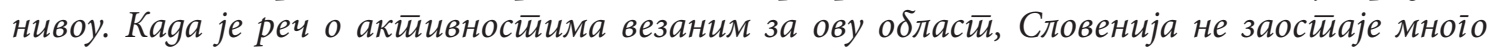

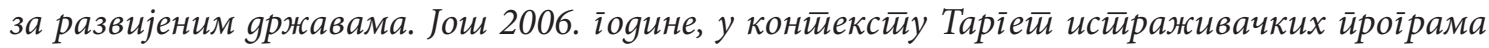
Словеначке аїениије за иситраживаюа, ӣокренуйа су gва йроїрама која се баве образованем и образованем за одрживи развој. Иако се у словеначким школама већ іодинама сировоgе мноіе акиичвносиии везане за ову иеммаичику, оне нису званично „означене као ЕСД. Као

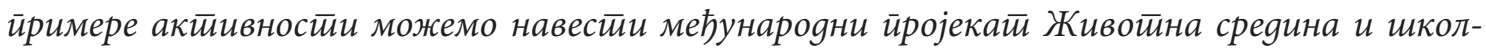
ска иницијайива, чији је оріанизатиор ОЕЦД/ЦЕРИ, а који је сйровеgен у йериоgу оg 1990. gо 1994. іолине, као и широку мрежу еко-школа, зgравих школа, УНЕСКО школа, и мноїих gруїих. Циль нашеі истираживаға био је да устиановимо gа ли су елемениии ЕСД-а йрисуйни у словеначким основним школама. Да бисмо овај ииль оствварили, анализирали смо словеначке

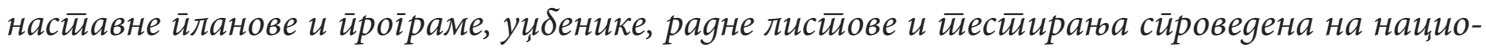

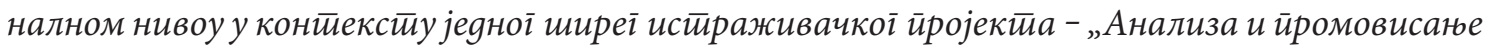

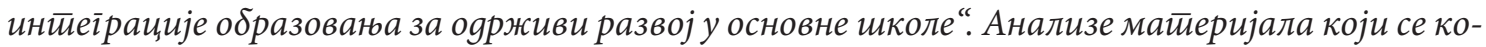
ристе у основној школи који, йо нашем миштеюьу, у великој мери уйичу на знаюе, вешиичне и

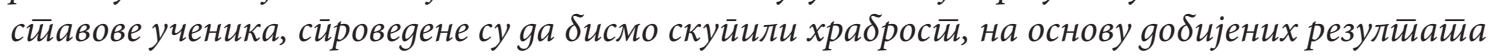
и йозивајући се на тиеорију (међународни и национални ЕСД gокументии), gа йреgложимо

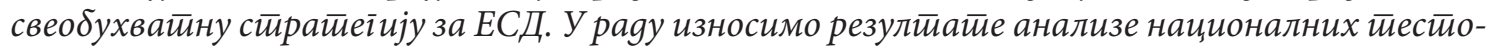
ва које сви учениии узрастй оg йейнаести іолина морају gа йолажу на крају основне школе. На основу кључних докуменатиа у вези са ЕСД-ом које су донели УНЕСКО, УНЕЦЕ, Евройска унија, Ујеgиюене нације и gруіе оріанизације, найравили смо криитеријуме за дебинисане ЕСД-а. Изабрали смо четирнаести кључних речи (оярживи развој, еколоіија, зgрав живой,

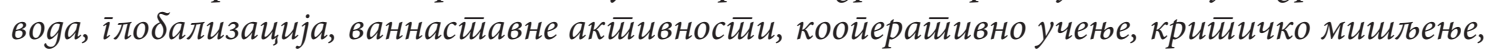

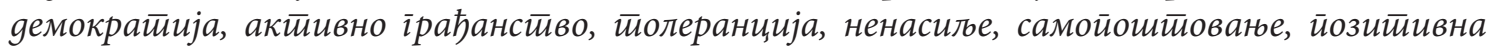
слика о себи). Ове ктучне речи користичли смо у анализи националних йестиова коришћених у школској їодини 2005/06, на йочейку ДЕСД-а. У анализи је коришћен квалийайивни ме-

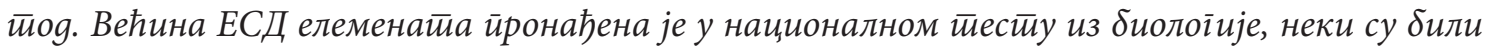

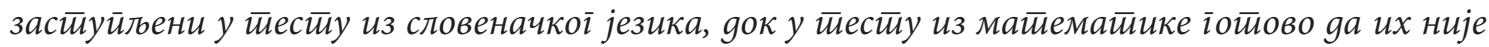
ни било. Истие анализе сировеgене су и на самом крају ДЕСД-а, зайо шйо смо желели gа уйврgимо gа ли је ДЕСД имао икаквоі ефекйа на израяу националних йестиова у Словенији.

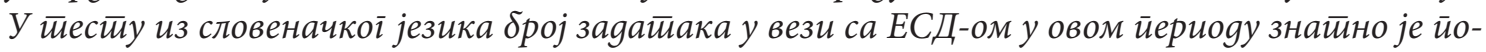
већан, али је затио број заgатиака у вези са ЕСД-ом био знайно сманен у националном йестиу

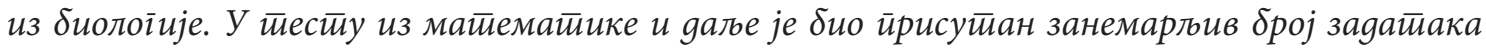

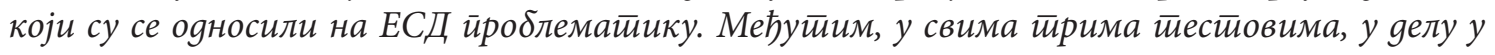




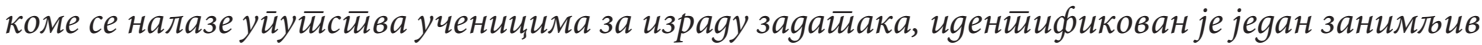
елеменай ЕСД-а. Пронашли смо gве кључне речи: самойоуздағе и йозийивна слика о себи. У националним йестиовима нисмо нашли саяржаје који би моїли gа се gовеgу у везу са слеgећим къучним речима: воgа, йолераниија и ненасиље. Смайрамо gа је барем кључна реч

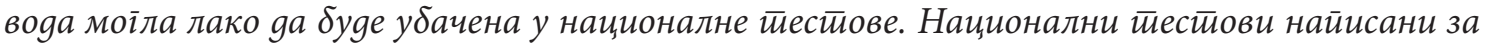
ученике у Словенији йоказују gа йестиови моїу gа буgу среgстиво за развој ЕСД-а, али юихов

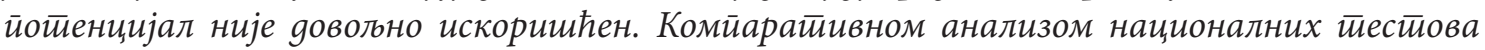
рађених на йочетику и крају ДЕСД-а устиановили смо gа у Словенији не може битии іовора о

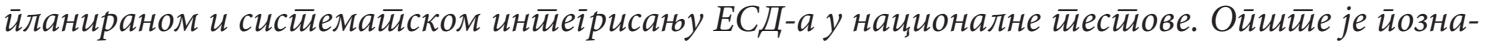

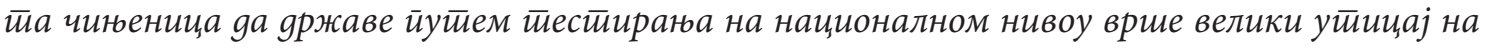

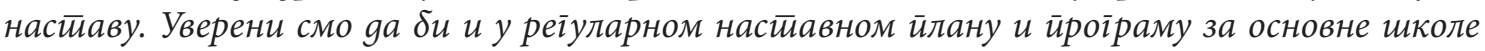
йостиојало више веза са ЕСД-ом ако би се елеменйи одрживоі развоја систиемайски уктучи-

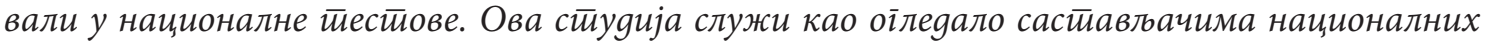

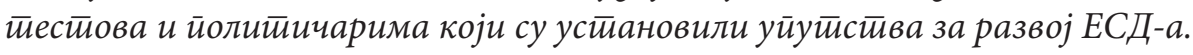

Клучне речи: Деценија образоваға за одрживи развој, образоване за оярживи развој, национални иестиови, оцениване на националном нивоу, основна школа. 